\title{
Peningkatan Hasil Belajar Ilmu Pengetahuan Sosial Siswa Menggunakan Model Kooperatif Tipe Student Team Achievement Division (STAD) di Sekolah Dasar
}

\author{
Firdaus $^{1)}$, Hamimah $^{2)}$, Desyandri3) \\ 1) Mahasiswa, Universitas Negeri Padang, Indonesia \\ ${ }^{2)}$ Pembimbing 1, Universitas Negeri Padang, Indonesia \\ 3) Pembimbing 2, Universitas Negeri Padang, Indonesia
}

Email: ${ }^{1)}$ firdaustanjung97@gmail.com, ${ }^{2)}$ hamimah@fip.unp.ac.id, ${ }^{3)}$ desyandri@fip.unp.ac.id

\begin{abstract}
Abstrak
Tujuan penelitian ini adalah untuk mendeskripsikan peningkatan hasil belajar siswa dalam pembelajaran IPS dengan menggunakan model kooperatif tipe Student Team Achievement Division ( STAD ) di kelas IV SDN 16 Campago Ipuh Bukittinggi. Jenis penelitian ini adalah Penelitian Tindakan Kelas dengan menggunakan pendekatan kuantitatif dan kualitatif yang mana Subjek penelitian ini adalah guru dan siswa kelas IV yang berjumlah 26 orang. Hasil penelitian menunjukkan perencanaan, pelaksanaan, dan hasil belajar siswa meningkat. Dengan demikian, dapat disimpulkan, dengan menggunakan model STAD dapat meningkatkan hasil belajar siswa dalam pembelajaran IPS.
\end{abstract}

Kata kunci: Hasil belajar, Student, Team, Achievement, Division

\section{The Improvement of Student Social Sciences Learning Outcomes with Cooperative Learning Model Type Student Team Achievement Division in 4 grade of Elementary School}

\begin{abstract}
The purpose of the research was to describe the student's learning outcomes in IPS learning with STAD model in the fourth grade of SDN 16 Campago Ipuh Bukittinggi. The kind of the research was Classroom action research that use quantitative and qualitative approaches in which the subject of this research are the teacher and 26 students of the fourth grade. The result of this research was to show of the increasing of the plan, process, and learning outcomes. In conclusion, STAD model can increase the student's learning outcomes in IPS learning.
\end{abstract}

Keywords: Learning outcomes, Student, Team, Achievement, Division, STAD 


\section{PENDAHULUAN}

Ilmu pengetahuan sosial (IPS) merupakan salah satu mata pelajaran yang diberikan dari SD/MI sampai ke perguruan tinggi. Pembelajaran IPS merupakan bagian dari pembelajaran di Sekolah Dasar yang sangat penting dalam mengembangkan kemampuan siswa untuk memahami lingkungan sosial di dalam kehidupan seharihari. Susanto (2016:139) menjelaskan bahwa Ilmu Pengetahuan Sosial adalah perpaduan antara ilmu sosial dan kehidupan manusia yang di dalamnya mencakup antropologi, ekonomi, geografi, sejarah, hukum, filsafat, ilmu politik, sosiologi, agama, dan psikologi.

Melalui mata pelajaran IPS di SD, siswa diharapkan memiliki pengetahuan dan wawasan tentang konsep-konsep dasar IPS, serta memiliki keterampilan dan sikap yang baik dalam memecahkan persoalan serta masalah hidup dalam sosial masyarakat yang kompleks dan penuh tantangan yang terjadi di lingkungannya. Di samping itu, pembelajaran IPS ditujukan agar terciptanya keadilan sosial dalam kehidupan manusia diperlukan aktivitas pendidikan yang mengakomodir seluruh keberagaman siswa (Desyandri, 2014). Jika kondisi ini dibiarkan terus menerus akan berakibat terhadap munculnya perilaku negatif. This condition leads to the emergence of behavior that is not characterized, civilized, and cultured, such as early childhood that does not respect the parents, peers, and society (Desyandri, 2017). Di samping itu, secara kuantitas seiring perkembangan zaman memperlihatkan kondisi perilaku peserta didik dan masyarakat yang semakin meng khawatirkan (Desyandri, 2018).

Pembelajaran yang dilakukan guru secara keseluruhan belum maksimal dan proses pembelajaran masih menggunakan pembelajaran konvensional yang didominasi oleh ceramah (Desyandri, 2012). Salah satu upaya peningkatan proses pembelajaran adalah selalu mencarikan dan menemukan terobosanterobosan baru atau inovasi dalam proses pembelajaran yang berdampak pada penanaman nilai-nilai karakter dan budaya bangsa (Desyandri, 2011). Salah satu inovasi tersebut adalah menggunakan Model Pembelajaran Kooperatif Tipe Student Team Achievement Division (STAD)

Dari pendapat di atas dapat diketahui bahwa tujuan pembelajaran Ilmu Pengetahuan Sosial (IPS) adalah mengembangkan kemampuan berfikir dan membina sikap yang baik siswa didalam kehidupan sosialnya sehari-hari baik dirumah, disekolah dan tempat dimanapun dia berada nantinya. Agar terwujudnya tujuan pembelajaran IPS di atas, maka pembelajaran IPS harus disajikan dengan cara membangkitkan minat dan perhatian siswa, memotivasi, melibatkan 
siswa secara aktif serta dapat meningkatkan perkembangan intelektual siswa. Kemudian seorang guru harus mampu menyusun dan melaksanakan strategi dan teknik pembelajaran yang aktif, inovatif, lingkungan, kreatif, efektif dan menarik (PAILKEM).

Dalam pembelajaran IPS idealnya adalah (1) Guru merencanakan pembelajaran dengan menyusun rencana pelaksanaan pembelajaran (RPP) , dimana kegiatan pembelajaran yang disusun guru harus sesuai dengan kegiatan pembelajaran yang dilaksanakan oleh guru pada proses belajar mengajar. (2) Guru hendaknya membuat pembelajaran yang bervariasi sehingga pembelajaran berpusat pada siswa yang menjadikan siswa aktif dan kreatif dalam pembelajaran. (3) Guru melakukan pembelajaran yang dilakukan secara berkelompok, sehingga membuat siswa aktif dan bertanggung jawab terhadap materi yang dipelajarinya. (4) Guru seharusnya dapat membimbing siswa untuk mengumpulkan suatu informasi yang nyata baik secara individu maupun kelompok. (5) Guru hendaknya dapat membimbing siswa untuk mengembangkan dan menyajikan materi dalam berkelompok. (6) Guru seharusnya menggunakan media dan model pembelajaran yang tepat sehingga pembelajaran akan menjadi bermakna dan menyenangkan bagi siswa. (7) Harus adanya komunikasi multi arah, seperti tanya jawab, diskusi, atau menggunakan model pembelajaran yang lebih interaktif. (8) Serta guru harus mampu memotivasi siswa yang dapat dilakukan dalam proses pembelajaran. Sehingga melahirkan interaksi guru dengan siswa.

Berdasarkan observasi yang peneliti lakukan pada tanggal 27 dan 28 juli 2017 di kelas IV SDN 16 Campago Ipuh, khususnya dalam pembelajaran IPS peneliti menemukan beberapa permasalahan dari aspek RPP di antaranya: 1) RPP yang dipakai guru masih belum memakai model pembelajaran yang tepat, 2) RPP yang dirancang tidak dijadikan pedoman guru dalam kegiatan pembelajaran. Sedangkan permasalahan dari aspek guru yaitu: 1) guru masih dominan dalam kegiatan pembelajaran (teacher center), 2) guru umumnya hanya menggunakan metode ceramah dalam penyampaian materi, sehingga kurang menarik perhatian, minat dan motivasi siswa dalam pembelajaran sehingga mengakibatkan siswa merasa jenuh dan pasif dalam pembelajaran, 3) dalam melaksanakan proses pembelajaran guru belum maksimal dalam menerapkan pola kegiatan belajar kelompok yang dapat memancing kerja sama dan kemampuan pemecahan masalah siswa, 4) dalam pembelajaran IPS guru lebih menekankan aspek pengetahuan (kognitif) semata, dan agak mengabaikan aspek sikap (afektif) dan keterampilan (psikomotor).

Sehubungan dengan hal di atas, mengakibatkan rendahnya hasil belajar siswa 
dalam pembelajaran IPS, seperti terlihat pada hasil ujian semester 1 siswa kelas IV SDN 16 Campago Ipuh Bukittinggi tahun ajaran $2017 / 2018$.

$$
\text { Untuk mengatasi permasalahan }
$$
tersebut, guru dapat mencari solusi salah satunya dengan menggunakan model pembelajaran agar tercapainya proses pembelajaran yang baik. Dari semua model pembelajaran kooperatif, peneliti memilih salah satu model yang dianggap tepat untuk digunakan dalam proses pembelajaran yaitu model kooperatif tipe Student Team Achievement Division (STAD) supaya kegiatan belajar siswa dalam pembelajaran IPS menjadi lebih aktif dan siswa berani mengungkapkan pendapatnya di dalam kelas. Sebagai salah satu tipe dari kooperatif, tipe $S T A D$ tidak jauh berbeda dengan tipe lainnya yaitu mengutamakan kerja sama dalam kelompok.

Dari uraian di atas, rumusan masalah yang ada dalam penelitian ini yaitu 1) Bagaimanakah Rencana Pelaksanaan Pembelajaran (RPP) IPS untuk peningkatan hasil belajar siswa dalam pembelajaran IPS dengan menggunakan model kooperatif tipe STAD di kelas IV SDN 16 Campago Ipuh Bukittinggi? 2) Bagaimanakah pelaksanaan pembelajaran IPS untuk peningkatan hasil belajar siswa dalam pembelajaran IPS menggunakan model kooperatif tipe STAD di kelas IV SDN 16 Campago Ipuh Bukittinggi? 3)Bagaimanakah peningkatan hasil belajar siswa dalam pembelajaran IPS menggunakan model kooperatif tipe $S T A D$ di kelas IV SDN 16 Campago Ipuh Bukittinggi?

\section{METODE PENELITIAN}

Jenis penelitian ini adalah Penelitian Tindakan Kelas (PTK). Penelitian ini telah dilaksanakan di SDN 16 Campago Ipuh Bukittinggi. Subjek penelitian ini adalah guru dan siswa kelas IV SDN 16 Campago Ipuh Bukittinggi dengan jumlah siswa 26 orang, yang terdiri dari 14 orang laki-laki dan 12 orang perempuan. Penelitian ini dilaksanakan sebanyak dua siklus. Siklus I dilaksanakan 2 kali pertemuan dan siklus II dilaksanakan 1 kali pertemuan.

Pendekatan yang digunakan adalah pendekatan kualitatif dan kuantitatif. Setiap siklus dalam penelitian ini dilaksanakan dengan tahap perencanaan, pelaksanaan, pengamatan, dan refleksi. Selain itu, penelitian ini dilaksanakan seara kolabotratif yaitu kerjasama antara peneliti yang melakukan tindakan sesuai perencanaan dengan guru kelas sebagai observer.

Data penelitian berupa hasil pengamatan, diskusi dari setiap tindakan perbaikan pembelajaran IPS tentang materi perkembangan teknologi produksi, komunikasi, dan transportasi melalui model kooperatif tipe $S T A D$ pada siswa kelas IV SDN 16 Campago Ipuh. Data tersebut tentang halhal yang berkaitan dengan perencanaan, 
pelaksanaan dan hasil pembelajaran. Sumber data penelitian adalah proses pembelajaran IPS tentang materi perkembangan teknologi produksi, komunikasi, dan transportasi melalui model kooperatif tipe $S T A D$ melalui enam tahap. Data diperoleh dari subjek yang diteliti yakni guru, dan siswa kelas IV SDN 16 Campago Ipuh.

Teknik pengumpulan data penelitian ini menggunakan observasi dan hasil tes maupun non tes. Instrumen dalam penelitian ini adalah lembar pengamatan, lembar tes, dan lembar penilaian. Lembar observasi digunakan untuk mengamati perencanaan (RPP), aktivitas guru, dan aktivitas siswa selama berlangsungnya pembelajaran IPS tentang materi perkembangan teknologi produksi, komunikasi, dan transportasi. Lembar tes terdiri dari 10 soal pilihan ganda dan 5 soal esai yang digunakan untuk mendapatkan data tentang hasil belajar siswa pada ranah kognitif. Sedangkan untuk lembar penilaian afektif menggunakan lembar pernyataan berbentuk daftar cek dan untuk penilaian psikomotor diambil dari pembuatan kliping.

Model analisa data kuantitatif yaitu terhadap hasil belajar siswa dengan menggunakan pendekatan persentase yang dirumuskan oleh Purwanto (2006:112) dengan rumus sebagai berikut :

$$
\mathrm{NP}=\frac{R}{S M} \times 100 \%
$$

Dimana: NP = Nilai yang diharapkan (dicari), $\mathrm{R}=$ Jumlah skor yang diperoleh, dan $\mathrm{SM}=$
Jumlah skor maksimal. Kriteria keberhasilan setiap tindakan adalah $75 \%$ sesuai dengan yang ditetapkan di SDN 16 Campago Ipuh Bukittinggi.

\section{HASIL SIKLUS I}

\section{Siklus I Pertemuan 1}

\section{Perencanaan}

Penilaian terhadap RPP dilaksanakan melalui lembar penilaian RPP dengan aspek penilaian yang terdiri dari 1) Kejelasan perumusan tujuan pembelajaran, 2) pemilihan materi ajar, 3) pengorganisasian materi ajar, 4) pemilihan sumber atau media pembelajaran, 5) kejelasan proses pembelajaran, 6) teknik pembelajaran, 7) kelengkapan instrumen.

Berdasarkan penilaian observer terhadap RPP yang telah disusun guru pada siklus I pertemuan 1, jumlah skor yang diperoleh adalah 23 dari skor maksimal 28 . Persentase skor yang diperoleh adalah $82,1 \%$. Hal ini menunjukkan bahwa kemampuan peneliti dalam menyusun RPP berada dalam kategori Baik (B).

\section{Pelaksanaan}

Pelaksanaan pembelajaran IPS dengan menggunakan model kooperatif tipe $S T A D$ di kelas IV SDN 16 Campago Ipuh dilaksanakan pada hari rabu tanggal 28 februari 2018 mulai pukul 10.30-12.15 WIB. Pembelajaran pada pertemuan pertama ini berlangsung selama 3 jam pelajaran, dengan alokasi waktu $3 \times 35$ menit. Berdasarkan RPP yang disusun 
pelaksanaan tindakan dibagi menjadi tiga tahap yaitu kegiatan awal, kegiatan inti, dan kegiatan akhir, dengan menggunakan langkah-langkah model STAD, yaitu 1) penyajian materi, 2) kegiatan belajar kelompok, 3) Pemeriksaan hasil kerja kelompok, 4) Tes individual, 5) Pemeriksaan hasil tes, 6) Penghargaan kelompok.

\section{Aktivitas guru}

Aspek guru dalam pembelajaran dengan metode STAD pada Siklus I pertemuan 1 ini belum tercapai dengan maksimal sesuai dengan rencana yang disusun. Berdasarkan hasil pengamatan aktivitas guru yang dilakukan observer selama pelaksanaan pembelajaran berlangsung pada siklus I pertemuan 1 jumlah skor yang diperoleh adalah 27 dari skor maksimal 32. Persentase skor yang diperoleh adalah $84,4 \%$ dan berada dalam kategori Baik (B).

\section{Aktivitas Siswa}

Pelaksanaan pembelajaran dengan metode STAD dari aspek siswa pada Siklus I pertemuan 1 ini belum terlaksana dengan maksimal sesuai dengan rencana yang telah disusun. Berdasarkan hasil pengamatan aktivitas guru yang dilakukan observer selama pelaksanaan pembelajaran berlangsung pada siklus I pertemuan 1 jumlah skor yang diperoleh adalah 27 dari skor maksimal 32. Persentase skor yang diperoleh adalah $84,4 \%$ dan berada dalam kategori Baik (B).

\section{Hasil Belajar}

Hasil belajar pada siklus I pertemuan 1 ini terdiri dari penilaian kognitif, afektif dan psikomotor sehingga diperoleh nilai rata-rata adalah 72,3. Ini berada di bawah KKM yang diharapkan yaitu 75 .

\section{Siklus I Pertemuan 2}

\section{Perencanaan}

Penilaian terhadap RPP dilaksanakan melalui lembar penilaian RPP dengan aspek penilaian yang terdiri dari 1) Kejelasan perumusan tujuan pembelajaran, 2) pemilihan materi ajar, 3) pengorganisasian materi ajar, 4) pemilihan sumber atau media pembelajaran, 5) kejelasan proses pembelajaran, 6) teknik pembelajaran, 7) kelengkapan instrumen.

Berdasarkan penilaian observer terhadap RPP yang telah disusun guru pada siklus I pertemuan 2, jumlah skor yang diperoleh adalah 25 dari skor maksimal 28. Persentase skor yang diperoleh adalah $89,2 \%$. Hal ini menunjukkan bahwa kemampuan peneliti dalam menyusun RPP berada dalam kategori Baik (B).

\section{Pelaksanaan}

Pelaksanaan pembelajaran IPS dengan menggunakan model kooperatif tipe STAD di kelas IV SDN 16 Campago Ipuh dilaksanakan pada hari rabu tanggal 8 Maret 2018 mulai pukul 10.30-12.15 WIB. Pembelajaran pada 
pertemuan pertama ini berlangsung selama 3 jam pelajaran, dengan alokasi waktu $3 \times 35$ menit. Berdasarkan RPP yang disusun pelaksanaan tindakan dibagi menjadi tiga tahap yaitu kegiatan awal, kegiatan inti, dan kegiatan akhir, dengan menggunakan langkah-langkah model $S T A D$, yaitu 1) penyajian materi, 2) kegiatan belajar kelompok, 3) Pemeriksaan hasil kerja kelompok, 4) Tes individual, 5) Pemeriksaan hasil tes, 6) Penghargaan kelompok.

\section{Aktivitas guru}

Aspek guru dalam pembelajaran dengan metode STAD pada Siklus I pertemuan 2 ini dilaksanakan sesuai dengan rencana yang disusun. Berdasarkan hasil pengamatan aktivitas guru yang dilakukan observer selama pelaksanaan pembelajaran berlangsung pada siklus I pertemuan 2 jumlah skor yang diperoleh adalah 29 dari skor maksimal 32. Persentase skor yang diperoleh adalah 90,6\% dan berada dalam kategori Sangat Baik (A).

\section{Aktivitas Siswa}

Pelaksanaan pembelajaran dengan metode $S T A D$ dari aspek siswa pada Siklus I pertemuan 2 ini dilaksanakan sesuai dengan rencana yang telah disusun. Berdasarkan hasil pengamatan aktivitas guru yang dilakukan observer selama pelaksanaan pembelajaran berlangsung pada siklus I pertemuan 2 jumlah skor yang diperoleh adalah 29 dari skor maksimal 32. Persentase skor yang diperoleh adalah 90,6\% dan berada dalam kategori Sangat Baik (A).

\section{Hasil Belajar}

Hasil belajar pada siklus I pertemuan 2 ini terdiri dari penilaian kognitif, afektif dan psikomotor sehingga diperoleh nilai rata-rata adalah 77 .

\section{HASIL SIKLUS II}

Hasil analisis refleksi pada siklus I menunjukkan penelitian belum berhasil sesuai dengan yang diharapkan, hal ini dikarenakan kurangnya kesesuaian antara pelaksanaan dengan perencanaan yang telah dibuat, karena itu pembelajaran dilanjutkan dengan siklus II.

\section{Perencanaan}

Lembar penilaian RPP yang digunakan pada siklus II sama dengan lembar pengamatan penilaian RPP siklus I. Berdasarkan pengamatan yang dilakukan oleh observer, skor yang diperoleh ialah 27 dari skor maksimal 28. Jadi, persentase skor yang diperoleh praktisi (peneliti) pada penilaian RPP siklus II adalah 96,4\% dengan kriteria sangat baik (A).

\section{Pelaksanaan}

Pelaksanaan pembelajaran IPS dengan menggunakan model kooperatif tipe STAD di kelas IV SDN 16 Campago Ipuh dilaksanakan pada hari rabu tanggal 14 Maret 2018 mulai pukul 10.30-12.15 WIB. Pembelajaran pada 
pertemuan pertama ini berlangsung selama 3 jam pelajaran, dengan alokasi waktu 3 x 35 menit. Berdasarkan RPP yang disusun pelaksanaan tindakan dibagi menjadi tiga tahap yaitu kegiatan awal, kegiatan inti, dan kegiatan akhir, dengan menggunakan langkah-langkah model $S T A D$, yaitu 1) penyajian materi, 2) kegiatan belajar kelompok, 3) Pemeriksaan hasil kerja kelompok, 4) Tes individual, 5) Pemeriksaan hasil tes, 6) Penghargaan kelompok.

\section{Aktivitas guru}

Berdasarkan hasil pengamatan yang dilakukan oleh observer terhadap aspek guru dalam pelaksanaan pembelajaran IPS dengan model STAD pada siklus II, jumlah skor yang diperoleh ialah 31 dari skor maksimalnya, yaitu 32. Dengan demikian, persentase skor rata-rata aspek guru adalah 96,8\%. Hal ini menunjukkan bahwa kriteria keberhasilan pelaksanaan pembelajaran dari aspek guru termasuk dalam kategori Sangat Baik (A).

\section{Aktivitas Siswa}

Dari hasil pengamatan aspek siswa dalam pelaksanaan pembelajaran dengan metode Role Playing siklus II jumlah skor yang diperoleh ialah 31 dari skor maksimal 32. Dengan demikian, persentase skor ratarata aspek siswa adalah 94,8\%. Hal ini menunjukkan bahwa kriteria keberhasilan pelaksanaan pembelajaran dari aspek siswa termasuk dalam kategori Sangat Baik (A).

\section{Hasil belajar}

Hasil belajar siswa pada siklus II ini sudah baik, hal ini terlihat dari rekapitulasi nilai dengan rata-rata adalah 84,6 dan hal ini sudah mencapai KKM. Secara keseluruhan hasil pembelajaran siklus II sudah lebih baik dari siklus I. Untuk itu, hasil belajar IPS dengan menggunakan model STAD bisa meningkatkan hasil belajar IPS siswa.

\section{PEMBAHASAN}

\section{Siklus I}

Sebelum memulai proses pembelajaran guru harus membuat perencanaan yang dimulai dengan membuat rancangan pembelajaran dalam bentuk rencana pelaksanaan pembelajaran (RPP). Standar kompetensi yang digunakan dalam pembelajaran IPS dengan menggunakan model kooperatif tipe STAD adalah mengenal perkembangan teknologi produksi, komunikasi, dan transportasi serta pengalaman menggunakannya. Sedangkan materi yang dibahas dalam RPP siklus I ini adalah perkembangan teknologi produksi dan komunikasi.

Berdasarkan diskusi peneliti dengan guru kelas IV SDN 16 Campago Ipuh Bukittinggi, dalam rancangan pembelajaran IPS dengan menggunakan model STAD ditemukan beberapa hal yang harus diperhatikan sebagai berikut 1) Pada karakteristik pemilihan materi ajar, pemilihan 
materi ajar kurang sesuai dengan karakteristik siswa, 2) Pada karakteristik pengorganisasian materi ajar yang tidak sesuai dengan alokasi waktu yang ditetapkan, 3) Pada karakteristik pemilihan sumber/media pembelajaran, sumber pembelajaran kurang sesuai dengan karakteristik siswa, 4) Pada karakteristik kejelasan proses pembelajaran yaitu langkahlangkah pembejaran tidak sesuai dengan alokasi waktu yang ditetapkan, 5) Pada karakteristik teknik pembelajaran, teknik pembelajaran kurang sesuai dengan lingkungan sekolah.

Dari analisis penelitian siklus I nilai rata-rata hasil belajar siswa adalah 74,6 dengan kualifikasi C (cukup) dimana dari 26 orang siswa hanya 13 orang siswa yang mencapai nilai ketuntasan (50\%). Hasil tersebut masih belum memenuhi standar ketuntasan belajar yang diharapkan sekolah yaitu 75. \%). Hal ini disebabkan karena siswa belum aktif dalam belajar dan belum terbiasa dengan pembelajaran kelompok sehingga siswa belum memahami materi pembelajaran. Berdasarkan hasil pengamatan siklus I yang diperoleh, maka direncanakan untuk melakukan perbaikan pada pembelajaran berikutnya atau perbaikan selama proses pembelajaran pada siklus II.

\section{Siklus II}

Bentuk rencana pelaksanaan pembelajaran pada siklus II ini tidak jauh berbeda dengan siklus I. Perbedaan hanya terletak pada materi yang diajarkan yaitu mengenal perkembangan teknologi transportasi, dan pembagian anggota kelompok ditukar. Sedangkan langkah-langkah pembelajarannya sama dengan siklus I yaitu menggunakan model kooperatif tipe $S T A D$.

Pembelajaran IPS menggunakan model STAD pada siklus II ini sudah berjalan dengan baik, ini dapat dibuktikan dengan nilai yang diperoleh siswa sudah meningkat yaitu dengan rata-rata 84,6.

Jadi jika dilihat dari hasil penilaian yang dilakukan, dapat dikatakan bahwa guru telah berhasil dalam meningkatkan hasil belajar siswa pada mata pelajaran IPS dengan menggunakan model STAD di kelas IV SDN 16 Campago Ipuh Bukittinggi. Selain itu perilaku siswa pun berubah menjadi lebih aktif dalam berdiskusi dan berani manyatakan pendapat, serta lebih bisa menghargai perbedaan yang ada dalam kelompok maupun kelasnya.

\section{SIMPULAN}

Berdasarkan data hasil penelitian dan pembahasan tentang upaya peningkatan pembelajaran IPS dengan menggunakan model kooperatif tipe STAD dapat disimpulkan sebagai berikut

1) Perencanaan Pembelajaran IPS di kelas IV SD dalam bentuk RPP dengan menerapkan model STAD maka guru bisa memakai model 
pembelajaran yang tepat sehingga bisa menarik minat siswa dalam belajar sehingga guru menjadikan RPP yang dirancang sebagai pedoman dalam kegiatan pembelajaran. 2) Pelaksanaan pembelajaran dengan model STAD ini dapat membuat siswa menjadi dominan dalam kegiatan pembelajaran, memiliki minat dan motivasi dalam belajar, semakin percaya diri dalam mengemukakan pendapat terutama dalam kegiatan belajar kelompok, menjadi lebih aktif karena pembelajaran tidak menekankan aspek kognitif. 3) Hasil belajar rata-rata kelas yang diperoleh dalam pembelajaran IPS dengan model STAD ternyata lebih meningkat dibandingkan dengan sebelumnya, dimana hasil belajar siswa pada siklus I pertemuan 1 dari penggabungan nilai kognitif, afektif, dan psikomotor hanya memperoleh rata-rata 72 dengan kualifikasi cukup (C). Selanjutnya pada siklus I pertemuan 2 adalah 77 dengan kualifikasi cukup (C). Sedangkan pada siklus II rata-rata yang diperoleh siswa adalah 85 dengan kualifikasi baik (B).

Berdasarkan simpulan di atas maka peneliti menyarankan hal-hal sebagai berikut 1) Pembelajaran IPS dengan menggunakan model kooperatif tipe $S T A D$ layak dipertimbangkan oleh guru untuk menjadi pembelajaran alternatif yang dapat digunakan sebagai referensi dalam memilih model pembelajaran. 2) Bagi peneliti yang ingin menerapkan bentuk pembelajaran ini, dapat melakukan penelitian serupa dengan materi yang lain. 3) Bagi guru-guru yang ingin menerapkan model pembelajaran kooperatif tipe $S T A D$ agar lebih kreatif dalam merancang pembelajaran yang sesuai dengan materi pembelajaran,

\section{DAFTAR RUJUKAN}

Desyandri. (2011). Peningkatan Pembelajaran Seni Musik Berbasis Pendidikan Budaya dan Karakter Bangsa di Pendidikan Dasar. In Seminar Internasional Etnik Serumpun Indonesia-Malaysia (pp. 1-15).

Desyandri. (2012). The Usage of Contextual Teaching and Learning (CTL) Approach to improve the process and learning outcome of Singing to the Student Class III Elementary School YPKK of Padang State University. Pedagogi: Jurnal Ilmu Pendidikan, 12(1), 36-52. Retrieved from http://pedagogi.ppj.unp.ac.id/index.php /pedagogi/article/view/231

Desyandri. (2014). Peran Seni Musik dalam Pendidikan Multikultural. Jurnal Pembangunan Pendidikan; Fondasi Dan Aplikasi IP PPs UNY, 2(1), 1-11. https://doi.org/http://dx.doi.org/10.218 31/jppfa.v2i1.2613

Desyandri. (2017). Internalization of Local Wisdom Values through Music Art as Stimulation of Strengthening Character Education in Early Childhood Education; A Hermeneutic Analysis and Ethnography Studies. In ICECE 4th (Vol. 169, pp. 13-16). Padang: Atlantis Press. Retrieved from https://www.atlantispress.com/proceedings/icece$17 / 25889722$

Desyandri. (2018). Nilai-nilai Kearifan Lokal 
untuk Menumbuhkembangkan Literasi Budaya di Sekolah Dasar. Sekolah Dasar: Kajian Teori Dan Praktik Pendidikan, 27(1), 1-9. https://doi.org/http://dx.doi.org/10.179 77/um009v27i12018p001

Hamalik, O. (2011). Proses Belajar Mengajar. Jakarta: PT Bumi Aksara.

Purwanto, Ngalim. (2006). Prinsip-prinsip dan Teknik Evaluasi Pengajaran. Bandung: PT Remaja Rosdakarya
Available on: http://ejournal.unp.ac.id/students/index.php/pgsd

Sanjaya, W. (2010). Strategi Pembelajaran Berorientasi Standar Proses

Pendidikan. Jakarta: Kencana

Slavin. (2009). Cooperative Learning Teori Riset dan Praktek. Bandung: Nusa Media 